\title{
Effect of bovine colostrum administration on plasma protein profile, growth, and survival in Red kid
}

\author{
Harouna Abdou ${ }^{\mathrm{a}, 1}$, Hamani Marichatou ${ }^{\mathrm{b}, 2}$, Jean-François Beckers ${ }^{\mathrm{c}, 3}$, \\ Isabelle Dufrasne ${ }^{\mathrm{a}, 1}$, Jean-Luc Hornick ${ }^{\mathrm{a}, *}$ \\ a Department of Animal Production, Faculty of Veterinary, University of Liege, 20 Boulevard de Colonster, B43, 4000 Liege, Belgium \\ b Department of Animal Production, Faculty of Agriculture, University Abdou Moumouni, PO Box 10960, Niamey, Niger \\ ${ }^{c}$ Department of Science Functional, Faculty of Veterinary, University of Liege, 20 Boulevard de Colonster, Building B41, 4000 Liege, \\ Belgium
}

\section{A R T I C L E I N F O}

\section{Article history:}

Received 23 May 2013

Received in revised form 5 December 2013

Accepted 8 December 2013

Available online 15 December 2013

\section{Keywords:}

Bovine Azawak

Colostrum

Plasma protein

Growth

Survival

Red kids

\begin{abstract}
A B S T R A C T
This study evaluated the effect of colostrum from Azawak cows on plasma protein profile, growth, and survival in Red kids from Niger. Forty (40) newborn kids were allocated to one of two treatment-groups: control (free access to water and the mother) and colostrum (free access to water and the mother, but with additional $50 \mathrm{~mL}$ of colostrum/animal/day of birth and $25 \mathrm{~mL} / \mathrm{animal} /$ day from the 2 nd to 15 th day of age). Blood samples were collected into EDTA vacutainer tubes by jugular puncture at 10 and 30 days of age. Total protein was quantified by the Biuret method. The agarose gel electrophoresis was used to determine the serum levels of albumin, $\alpha$-globulin, $\beta_{1}$-globulin, $\beta_{2}$-globulin, $\gamma$-globulin and the albu$\mathrm{min} /$ globulin ratio. The animals from the colostrum group showed higher body weight and average daily gain when compared to the control group $(P<0.001)$. The average concentration in protein at the both sampling times reached higher values in the colostrum than in the control group. At D10, the colostrum group tended $(P<0.07)$ to show higher levels of $\alpha$-globulin and had higher values $(P<0.05)$ for $\beta_{1}$-globulin. At D30, total protein and $\beta_{2}$-globulins were higher in colostrum group. Colostrum from Azawak cows seems to have positive effects on some plasma proteins levels and on growth rate in Red kids.
\end{abstract}

(c) 2014 Elsevier B.V. All rights reserved.

\section{Introduction}

In ruminants, owing to the epitheliochorial nature of the placenta (Silim et al., 1990), the transmission of antibodies

\footnotetext{
* Corresponding author. Present address: Laboratory of Nutrition, Department of Animal Production, Faculty of Veterinary, University of Liege, 20 Boulevard de Colonster, B43, 4000 Liege, Belgium. Tel.: +32 043664131; fax: +32 043664122.

E-mail addresses: hanafiou82@yahoo.fr (H. Abdou), marimani_m@yahoo.fr, maricha@refer.ne (H. Marichatou), jfbeckers@ulg.ac.be (J.-F. Beckers), Isabelle.Dufrasne@ulg.ac.be (I. Dufrasne), jlhornick@ulg.ac.be (J.-L. Hornick).

1 Tel.: +32 043664131; fax: +32043664122.

2 Tel.: +227939165 31; fax: +227 20316612 .

3 Tel.: +32 043664161; fax: +32043664165.
}

to fetus fails during the pregnancy (Rawal et al., 2008). At birth, newborn is thus gamma-globulin deprived (Castro et al., 2005) while shifting from a healthy to a hostile environment (Alloncle, 1980; Rawal et al., 2008). The survival of young animals is of great concern for producers. As a rule, the mortality rate is higher from zero to three months of age in goat (63.4\% in 2010 at the Secondary Goat Farm Center of Maradi) and other species (N'Diaye-Wereme et al., 1998). These losses greatly affect the profitability of the farm.

Colostrum administration is vital for newborn (Marion et al., 2002; Stelwagen et al., 2009), especially for twins (Hamadeh et al., 2013; Nowak and Poindron, 2006). Several authors (Tuscherer et al., 2000; Edwards, 2002; Le Dividich et al., 2004) showed that defect in colostrum intake within 24-48 h (h) after parturition is related to newborn casualties. In Niger, where rearing conditions are precarious, 
dairy females do not produce enough colostrum and milk that could cover the needs of the newborns, enhancing the risk for a young animals to die. To our knowledge, no work focused on the production of colostrum in the Red goat. But Oumara (1986) indicated that its average daily milk production reach only $0.75 \mathrm{~kg} / \mathrm{d}$. It is possible to assist kids with bovine colostrum (N'Diaye-Wereme et al., 1998; King et al., 2008). Administration of heterologous colostrum also has been yet experienced in pig with good results (Huguet et al., 2007). Indeed, the bovine colostrum contains growth promoters and immunological compounds potentially useful for other species such as piglets, kids and lambs (Godden et al., 2009). Bovine colostrum supplementation in goat is fewly documented in the literature, especially at plasma level. The aim of this study was thus to evaluate the impact of an Azawak colostrum load in Red kids on their plasma protein profile, growth rate, and survival.

\section{Materials and methods}

\subsection{Experimental site}

The study was conducted at the Secondary Goat Farm Center of Maradi (SCGFM) in Niger, from September 2011 to October 2011. Average ambient daytime temperature is $35^{\circ} \mathrm{C}$ and annual rainfall is between 600 and $700 \mathrm{~mm}$. The town of Maradi is located about $600 \mathrm{~km}$ south-east of Niamey between $13^{\circ}$ and $15^{\circ} 26^{\prime}$ North and $6^{\circ} 16^{\prime}$ and $8^{\circ} 33^{\prime}$ East. SCGFM is located $3.5 \mathrm{~km}$ East of Maradi and covers an area of 1850 ha. Semi-intensive rangelands used are composed, according to Naba (2001), of a herbaceous cover (Andropogon gayanus, Cenchrus bifloris, Eragrotis tremula, Commelina forskalaei, Corchorus tridens, Jacquenontia tamnifoni) and ligneous species (Sclerocarya birrea, Polystigma reticulatum, Acacia albida, Acacia nilotica, Guiera senegalensis, Annona senegalensis, Balanites aegyptiaca, Boscia senegalensis, Combretum glutinosum, Combretum micrahum, Prosopis africana, Tamarindus indica).

\subsection{Colostrum collection and analysis}

The colostrum samples were obtained from two multiparous Azawak zebu cows (second lactation number), within one hour of calving. The cows were from the Sahelian Experimental Station of Toukounous (SEST) located $200 \mathrm{~km}$ north Niamey $\left(14^{\circ} 31^{\prime}\right.$ North and altitude $3^{\circ} 18^{\prime}$ East longitude). They were vaccinated against Contagious Bovine Pleuropneumonia (CBPP). The animals were on rangeland dominated according to Chaibou (2005) by grasses (Aristida mutabilis, A. mutabilis, Cenchrus biflorus, Eragrostis tremula, Schoenfeldia gracilis, Panicum laetum) and wood (Maerua crassifolia, Salvadora persica). The pregnant and dairy females were supplemented during the dry season with cotton seed $(2 \mathrm{~kg})$. The colostrum was analyzed for chemical composition and immunoglobulins content (Table 1). Colostrum immunoglobulins (Ig) and lactoferrin (Lf) were measured at the Center of Rural Economy of Marloie (Belgium) by ELISA, following the manufacturer's recommendations (Bethyl ${ }^{\circledR}$ quantitative sandwich ELISA, USA). Dry matter (DM), crude Ash, nitrogen-free extract (NFE), ether extract (EE) and total nitrogenous
Table 1

Components mean concentrations $(\mathrm{g} / \mathrm{L})$.

\begin{tabular}{lc}
\hline Composition $(\mathrm{g} / \mathrm{L})$ & Means \pm SD $(n=7)$ \\
\hline IgG & $22.5 \pm 9.7$ \\
IgA & $3.3 \pm 2.1$ \\
IgM & $1.7 \pm 0.8$ \\
Lactoferrin & $0.2 \pm 0.1$ \\
DM & $149.8 \pm 15.3$ \\
CP & $67.6 \pm 9.2$ \\
EE & $28.9 \pm 0.2$ \\
NFE & $43.4 \pm 3.2$ \\
Ash & $9.9 \pm 0.7$ \\
Ca & $1.3 \pm 0.2$ \\
P & $1.3 \pm 0.2$ \\
K & $1.4 \pm 0.2$ \\
Na & $0.7 \pm 0.2$ \\
Mg & $0.2 \pm 0.0$ \\
\hline
\end{tabular}

matter (TNM) were measured according to the methods of the Association of Official Analytical Chemists (AOAC, 2006). Calcium (Ca) and magnesium (Mg) were determined by atomic absorption, potassium (K) and sodium (Na) by flame emission and phosphorus (P) spectrophotometrically.

\subsection{Animals and experimentation}

The experimental protocol was approved by the laboratory of Animal production/Faculty of Agriculture/University of Abdou Moumouni (Niamey, Niger) in collaboration with the directorate of Niger's Veterinary Services. The experimental kids were obtained from 9 singletons and 11 twins kiddings. Singletons were alternatively allocated to either the control or the experimental group and twins were randomly allocated to either group, but sex ratio was preserved insofar as possible. The control group (ConG) had free access to water and the mother and the colostrum group (ColG) were offered in nursing bottle additional $50 \mathrm{~mL}$ of Azawak colostrum/animal the day of birth (D1) within $12 \mathrm{~h}$ of kidding and $15 \mathrm{~mL}$ colostrum/animal/d from the D2 to D15. During the day, kids were maintained on semi-intensive rangeland. They were kept at night in permanent shed. Animals grazed under the guidance of shepherds and at night they received biweekly a supplement of concentrates (wheat bran, cottonseed meal). In addition, they had free access to licks in racks. Water was given ad libitum. Each animal was identified by an alpha-numeric number indicating the affiliation to the park, the row of birth, and the sex. Fig. 1 presents the experimental design of the study.

\subsection{Measurements and samples}

The animals were weighted weekly using a balance with maximum load $150 \pm 0.1 \mathrm{~kg}$ and death occurrences were registered daily.

Blood samplings were performed at D10, the moment the jugular veins was easy to access and at D30. Samples ( $10 \mathrm{~mL} /$ animal) were performed by jugular puncture in EDTA vacutainer tubes (Terumo Corporation, Tokyo, Japan). Samples were transferred 40 min after collection to the laboratory and centrifuged at $1000 \mathrm{rpm}$ for $25 \mathrm{~min}$. Plasmas 


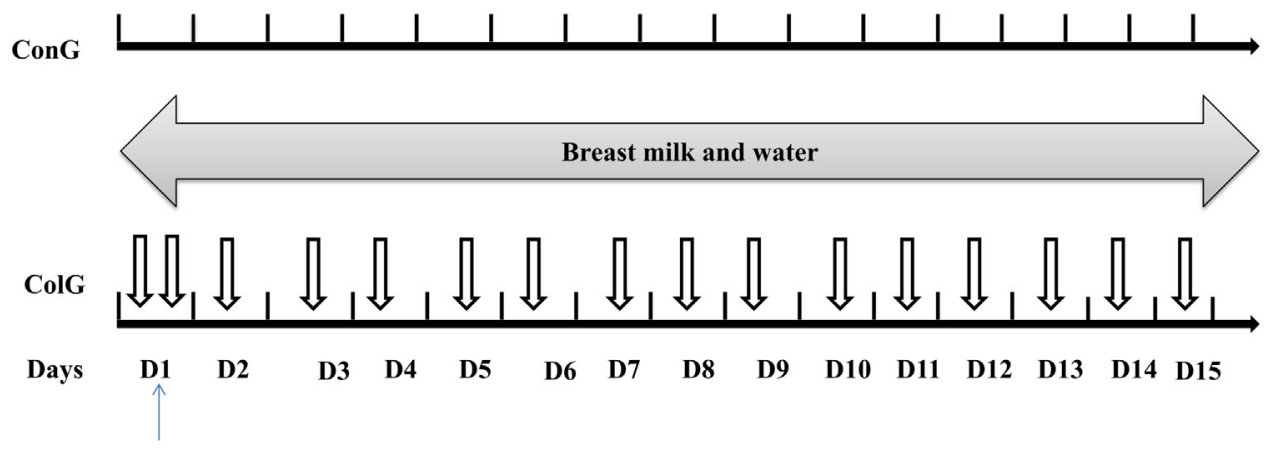

Birth<smiles>C=CC=CC(=O)C=C</smiles>

( $15 \mathrm{~mL}$ colostrum)

Fig. 1. Experimental design.

obtained were stored in Eppendorf at $-20^{\circ} \mathrm{C}$ until analysis at the Biochemistry Unit of the Faculty of Veterinary Medicine, University of Liege, Belgium. Total plasma protein was obtained by the Biuret method. Protein fractions (albumin, $\alpha$-globulin, $\beta_{1}$ and $\beta_{2}$ globulins, $\gamma$-globulins) were separated by electrophoresis. The albumin/globulin ratio was calculated.

Electrophoresis was performed on agarose gel following the manufacturer's recommendations (Hydragel protein K20, SEBIA, Lisse, France). Samples were thawed at $20^{\circ} \mathrm{C}$ for $30 \mathrm{~min}$. The procedure was performed by zone electrophoresis in which the migration is carried on horizontal support made of a porous medium, a strip of blotting paper and the agarose gel. Ten microliters of plasma were put for $4 \mathrm{~min}$ in numbered wells. The films were transferred to an electrophoresis tank (K20 SEBIA, Reference No. 1400) during $20 \mathrm{~min}$ at $90 \mathrm{~V}$. After migration and revelation films were placed in a colored bath (Coomassie Blue) approximately $5 \mathrm{~min}$ and then distained in acetic acid and dried at $80^{\circ} \mathrm{C}$ in an incubator-dryer (IS 80 SEBIA, Reference No. 1420) while $15 \mathrm{~min}$. The use of phoresy software (device used to view the various profiles) allowed the scanning of films to establish the electrophoresis curves showing the concentration rate of protein fractions. The separation points between profiles of plasma fractions were scored manually on phoresy software. All samples were analyzed by the same people. The absolute concentrations $(\mathrm{g} / \mathrm{L})$ of fractions were calculated by multiplying the percentage of each fraction by the total protein concentration determined before.

\subsection{Statistical analysis}

Body weight (BW), average daily gain (ADG) and plasma proteins data were analyzed according to a mixed model (SAS, 1999) including the effects of treatment, time, sex and their interactions. This model included a type 1 auto regression covariance structure for repeated data measured on the same animal. Means were compared using a Student's $t$ test with Tukey adjustment. Changes with time in concentration levels were compared according to contrast analysis. The selected threshold of significance was fixed at $5 \%$. As for survival, data were analyzed according the chi square test.

\section{Results}

\subsection{Plasma protein}

Table 2 presents least squares means \pm standard error for total plasma parameters concentrations and ratio in ColG and ConG. The group effect tended to be significant for total protein levels ( 58.5 vs $55.6 \mathrm{~g} / \mathrm{L}$ in ColG and ConG respectively, $P<0.06$ ) but no time nor interaction effect was observed. At D10, ColG tended to have higher values than ConG $(+2.7 \mathrm{~g} / \mathrm{L}, P<0.1)$ and the difference was significant at D30 $(+5.2 \mathrm{~g} / \mathrm{L}, P<0.05)$. In ColG, the total protein remained similar between times but it decreased significantly in ConG $(P<0.05)$. Plasma albumin did not show treatment effect, but values decreased highly significantly with age (4.8 vs 4.2) in ColG and ConG, respectively, $P<0.01$ ).

The alpha-globulin concentration levels tended to be higher in ColG than in ConG at both sample times (4.6 vs 4.1 and 4.7 vs 4.3 , at D10 and D30, respectively, $P<0.1$ ). From D10 to D30, changes were not significant. In addition, no effect of interaction was observed.

Plasma beta 1 globulin concentrations increased with age (9.9 vs $11.6 \mathrm{~g} / \mathrm{L}$ in ColG and 8.7 vs 10.5 in ConG, at d10-d30 respectively, $P<0.05)$. No interaction effect was observed but in ConG, the increase tended to be significant $(+1.8 \mathrm{~g} / \mathrm{L}, P=0.08)$. Regarding the change in beta1 globulin from D10 to D30, it was similar between the two groups.

As for beta2 globulin, the mean levels differed significantly between the two groups ( $3.1 \mathrm{vs} 2.3 \mathrm{~g} / \mathrm{L}$, in ColG and ConG respectively, $P<0.05$ ). Levels remained similar between the two ages, and no interaction effect was observed. Although no group difference was observed at D10, ColG showed higher plasma concentrations than ConG (4.1 vs. $2.2, P<0.05)$ at D30.

Surprisingly, in the case of plasma gammaglobulin, neither effect of group, time, or interaction, nor that of a contrast could be observed.

Considering the total plasma globulin, only a significant effect of treatment was observed (32.1 vs $29.1 \mathrm{~g} / \mathrm{L}$ in ColG 
Table 2

Total and fractions plasma proteins $(\mathrm{g} / \mathrm{L})$ at $\mathrm{d} 10$ and d30 of age in kids that received or not a supplement of bovine colostrum during the first $15 \mathrm{~d}$ of life.

\begin{tabular}{|c|c|c|c|c|c|c|c|c|c|}
\hline \multirow[t]{2}{*}{ Plasma fractions } & \multicolumn{2}{|l|}{ D10 } & \multicolumn{2}{|l|}{ D30 } & \multicolumn{4}{|c|}{ Levels of significance } & \multirow[t]{2}{*}{ SEM } \\
\hline & ColG $(n=18)$ & ConG $(n=16)$ & $\operatorname{ColG}(n=18)$ & ConG $(n=16)$ & $G^{1}$ & $T^{2}$ & $G \times T$ & $\Delta_{\mathrm{ColG}}$ vs $\Delta_{\mathrm{ConG}^{3}}$ & \\
\hline Total protein & $59.8^{\mathrm{aA}}$ & $57.1^{\mathrm{aA}}$ & $58.1^{\mathrm{aA}}$ & $53.2^{\mathrm{bB}}$ & $\mathrm{ns} \dagger$ & ns & ns & ns & 1.70 \\
\hline Albumin & $28.6^{\mathrm{aA}}$ & $27.8^{\mathrm{aA}}$ & $23.8^{\mathrm{aB}}$ & $23.6^{\mathrm{aB}}$ & ns & $* *$ & ns & ns & 1.40 \\
\hline$\alpha$-Globulin & 4.6 & 4.1 & 4.7 & 4.3 & $n s \dagger$ & ns & ns & ns & 0.21 \\
\hline$\beta_{1}$ globulin & 9.9 & $8.7^{\mathrm{A}}$ & 11.6 & $10.5^{\mathrm{B}}$ & ns $\dagger$ & $*$ & ns & ns & 0.73 \\
\hline$\beta_{2}$ globulin & 3.1 & 2.3 & $4.1^{\mathrm{a}}$ & $2.2^{\mathrm{b}}$ & $*$ & ns & ns & ns & 0.50 \\
\hline$\gamma$-Globulin & 14.5 & 13.8 & 13.9 & 12.0 & ns & ns & ns & ns & 0.80 \\
\hline Globulin & 32.1 & 29.1 & $34.3^{\mathrm{a}}$ & $29.0^{\mathrm{b}}$ & $*$ & ns & ns & ns & 1.72 \\
\hline Alb/Glob & 0.91 & 0.97 & 0.77 & 0.90 & ns & ns & ns & ns & 0.20 \\
\hline
\end{tabular}

a,b Within period treatment effect. For a same period and a same line, values assigned with different uppercase letters are significantly different $(P<0.05)$.

$\mathrm{A}, \mathrm{B}$ Within treatment period effect. For a same treatment and a same line, values assigned with different uppercase letters are significantly different $(P<0.05)$.

ns: $P>0.05 ;{ }^{\dagger} P<0.1 ;{ }^{*} P<0.05 ;{ }^{* *} P<0.01$

$1 \mathrm{G}$ : group effect.

$2 T$ : time effect.

$3 \Delta$ : difference in time within a treatment.

and ConG respectively, $P<0.05)$. The difference between the two groups was significant at D30.

No significant effect on the albumin/globulin ratio was observed.

\subsection{Growth and survival}

Table 3 presents data on growth characteristics. At birth, the BW of the two groups was similar $(1.7 \mathrm{~kg})$. After this period until the end of the trial, the BW increased linearly with time in both group, but with almost twice higher value for the slope of the growth curve in ColG than in ConG $(P<0.001)$, allowing to reach respectively $+1.1 \mathrm{~kg} \mathrm{vs}+0.6 \mathrm{~kg}$ weight gain at D29 $(P<0.001)$. Within the days, the overall ADG increased until D22 and decreased afterwards. However, the maximum value appeared earlier in ConG (D15) than in ColG (D22). The difference between the two groups strengthened with time (close to $30 \mathrm{~g} / \mathrm{d}$ at D8 and D15 and $60 \mathrm{~g} / \mathrm{d}$ at D22 and D29. As a whole, ColG had largely higher ADG than ConG $(P<0.001)$.

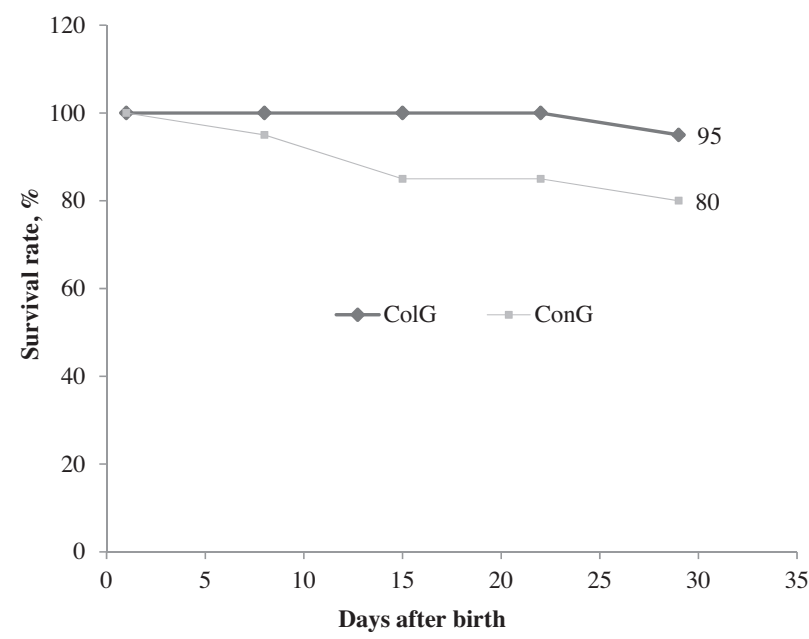

Fig. 2. Survival rate evolution of kids that received or not a supplement of colostrum during the 15 first day of life. ColG: colostrum group, ConG: control group
Fig. 2 shows the evolution of survival rate in the two groups. Gobally, 5 casualities were recorded, i.e., 1 (5\%) in ColG vs 4 (20\%) in ConG. Casualties occurred after diarrheal enteritis (25\%) and respiratory diseases (75\%).

\section{Discussion}

\subsection{Plasma protein}

For total protein, it was first observed a trend for a higher level in ColG at D10, then a significant difference at D30. In addition, statistical analysis showed that neither time nor the interaction $(G \times T)$ effects influenced the total plasma protein. Previous studies showed similar effects in the same species (Rodríguez et al., 2009; Moretti et al., 2012). For example, Moretti et al. (2012) found a significant difference in favor to a group of kids which received bovine lyophilized colostrum. According to Mayer et al. (2002), the protein from colostrum, given the first day of life cross the intestinal barrier, following an endocytic process. Presumably, a similar phenomenon occurred in this experiment, but, additionally, an extra-nutritional effect should have operated afterwards and strengthened the differences between the groups. The decrease in plasma total protein with time observed in this experiment is in agreement with results of Lima et al. (2009), who offered bovine colostrum to kids until $60 \mathrm{~d}$ of age. The highest concentration in total protein was obtained at $48 \mathrm{~h}$ of age and levels decreased thereafter. In another experiment, Lima et al. (2013) did not observe such a decrease with time. In the present trial, the slope of the decrease was weak and similar in the two groups. The trend for an overall difference between the two groups could be ascribed to a positive effect of cow colostrum on plasma protein homeostasis. In addition, plasma protein observed in ColG was much higher $(+1.7,+5.8$, and $+5.4 \%)$ than those $(57.7,55.5$ and $55.7 \mathrm{~g} / \mathrm{L})$ observed by Lima et al. (2013), using either fresh or reconstituted bovine colostrum containing $45-55 \mathrm{mg} / \mathrm{mL}$ of IgG, or poor bovine colostrum at $15-25 \mathrm{mg} / \mathrm{mL}$. These results suggest that colostrum from cow is able to maintain high levels of proteins in plasma of kids and that this value is probably similar, and possibly higher, than that obtained with goat colostrum. 
Table 3

Body weight and ADG (means \pm standard error) of kids that received or not a supplement of bovine colostrum during the first $15 \mathrm{~d}$ of live.

\begin{tabular}{|c|c|c|c|c|}
\hline \multirow[t]{2}{*}{ Measurements } & \multirow[t]{2}{*}{ Days } & \multicolumn{2}{|l|}{ Groups $^{1}$} & \multirow[t]{2}{*}{ Levels of significance } \\
\hline & & ColG & ConG & \\
\hline \multirow[t]{6}{*}{$\mathrm{BW}(\mathrm{kg})$} & d0 & $1.7 \pm 0.1^{\mathrm{a}}$ & $1.7 \pm 0.1^{\mathrm{a}}$ & $n s^{2}$ \\
\hline & $\mathrm{d} 8$ & $2.6 \pm 0.1^{b}$ & $2.3 \pm 0.1^{\mathrm{b}}$ & $*$ \\
\hline & $\mathrm{d} 15$ & $3.6 \pm 0.1^{c}$ & $3.1 \pm 0.1^{c}$ & $* * *$ \\
\hline & $\mathrm{d} 22$ & $4.5 \pm 0.1^{d}$ & $3.6 \pm 0.1^{d}$ & $* * *$ \\
\hline & $\mathrm{d} 29$ & $5.6 \pm 0.1^{e}$ & $4.2 \pm 0.1^{e}$ & $* * *$ \\
\hline & Significance & Group $^{* * *}$ & Time $e^{* * *}$ & Group $\times$ time $e^{* * *}$ \\
\hline \multirow[t]{5}{*}{$\mathrm{ADG}(\mathrm{g} / \mathrm{d})$} & $\mathrm{d} 8$ & $114.8 \pm 3.8^{\mathrm{a}}$ & $80.4 \pm 3.8^{a}$ & $* * *$ \\
\hline & $\mathrm{d} 15$ & $130.3 \pm 3.8^{\mathrm{b}}$ & $98.4 \pm 3.9^{\mathrm{b}}$ & $* * *$ \\
\hline & $\mathrm{d} 22$ & $152.5 \pm 3.8^{c}$ & $90.7 \pm 3.9^{c}$ & $* * *$ \\
\hline & $\mathrm{d} 29$ & $144.3 \pm 3.9^{d}$ & $85.7 \pm 3.9^{d}$ & $* * *$ \\
\hline & Significance & Group $^{* * *}$ & Time $e^{* * *}$ & Group $\times$ time $e^{* * *}$ \\
\hline
\end{tabular}

1 a, b, c, d, e: in the same column, means without common upper-case letter differ $(P<0.05)$.
2 ns: $P>0.05 ;{ }^{*} P<0.05 ;{ }^{* *} P<0.01 ;{ }^{* * *} P<0.001$.

For albumin, the concentration levels in the both groups significantly decreased between the two periods. Synthesized in the liver, albumin is the most represented protein in plasma, at about $50-65 \%$ of total protein (Kaneko et al., 1997). This molecule is essential for the survival of the newborn. Indeed, this protein fraction allows maintaining the oncotic pressure of the blood and transports numerous substances such as fatty acids, calcium, vitamins A and D, antibiotics, steroid hormones (Payne and Payne, 1987). It is dosed to assess the nutritional status of an animal. It is known that in healthy ruminants, changes in serum albumin concentration requires at least one month to be detected, owing to the low turnover - low degradation and synthesis rate - of this protein (Payne and Payne, 1987). Albumin is readily absorbed at the same time as immunoglobulin by the intestinal mucosa of the newborn kid, during the first $24 \mathrm{~h}$ of life; Lima et al. (2009) observed that its concentrations decreased after $48 \mathrm{~h}$ of age in kids receiving cow colostrum, to reach similar values as to control at $25 \mathrm{~d}$ of age. This suggests a higher turnover for albumin from cow. The poor nutritional conditions met in the SCGFM could explain the decrease in plasma albumin observed in both groups and the parallel decrease is not surprising.

Regarding globulins $(\alpha, \beta$ and $\gamma$ ), they are a heterogeneous family of proteins that play a role in the inflammatory response, the transportation of various lipophilic compounds, the homeostasis and the production of antibodies. Although only numerical, the initial higher plasma $\alpha$-globulin, $\beta_{1}, \beta_{2}$ and $\gamma$-globulins levels in ColG, associated with a parallel or higher increase with time when compared to ConG could mean that colostrum provided a competitive advantage to supplemented animals. Ben Romdhane et al. (2001) observed such an increase in camels. Compared to data of literature, the globulin $(\alpha, \beta$ and $\gamma$ ) levels obtained in this study are higher than those reported by Lima et al. (2013) who obtained less than $20 \mathrm{~g} / \mathrm{L}$ for the total globulins though their colostrum were richer in globulin than the present one. Data of the present study were in the ranges of $27.0-39.0 \mathrm{~g} / \mathrm{L}$ interval reported by Kaneko et al. (1997) as indicating a good state of nutrition in domestic animals.
In the case of $\gamma$-globulins, differences were not significant. It is not excluded that kids substituted partially the intake of goat colostrum by that of the additional one. It would be worth discriminating in the plasma of kids the immunoglobulin fractions derived from cow and from the mother, and to evaluate their specific half-life. The fall in plasma Ig is physiological. After $24 \mathrm{~h}$, the intestinal barrier losts its capacity to macromolecules internalization and immunoglobulins provide at this stage only local intestinal protection (Moretti et al., 2012). Hadorn and Blum (1997) observed the same effect in calves. Again, Argüello et al. (2004) observed that kids receiving various types of goat colostrum (chill, frozen) expressed maximum levels of Ig at about 24-36 h after birth. Recently Lima et al. (2009) showed that, parallel to total protein, the highest concentration of gamma-globulin in goat kid receiving cow colostrum was obtained at $48 \mathrm{~h}$ of age after birth.

Furthermore, it is important to note that the present concentrations of $\gamma$-globulins although obtained later, were similar to that obtained before $5 \mathrm{~d}$ of age by Moretti et al. (2012) in kids that received a colostrum supplementation.

The results of the present study suggest thus the existence of a positive correlation between colostrum intake and improvement of the plasma protein status.

\subsection{Growth and survival}

In this study, the significant growth rate difference observed between ColG and ConG could be explained only partly by the intake of supplemental bovine colostrum, because not only these differences increased with time, but also a maximum ADG was observed at the end of the experiment in ColG, by contrast to ConG that expressed the maximum - close to the minimum of the ConG - at the beginning of the experiment. In a previous study, Abdou et al. (2013) observed a highly significant long term - far after the end of the supplementation - difference between the group of animals which were fed colostrum and the control group. In addition, the important increases in BW and ADG recorded all over the present trial in animals receiving bovine colostrum were in agreement with results 
of Le Huërou-Luron et al. (2004) and Boudry et al. (2008) who showed the efficacy of bovine colostrum on growth in other species at weaning.

The overall results of this work meet those of Moretti et al. (2010) who indicated a better steady-state of kids after supplemental intake of colostrum. This may be directly associated to the presence of various nutrients in colostrum. Besides providing energy and protein, the supplementation in colostrum probably helped bringing additional levels of vitamins (A and E) and minerals (zinc, selenium and iodine) which gave animals a way to develop and maintain a stronger immunity (Rawal et al., 2008; Morales-delaNuez et al., 2011). Colostrum is also rich in lactoferrin, which plays an important role in defending the body against pathogens (Ajello et al., 2002; Di Mario et al., 2003; Rawal et al., 2008). Indeed, owing to its very strong affinity for iron, it promotes its absorption by the intestinal mucosa of newborns and limits its availability for pathogens (Yamauchi et al., 1998).

In addition, colostrum provides at low concentration polypeptidic compounds such as cytokines (IL-1 $\beta$, IL-6, IFN-7 and IL-1) belonging to the family of specific and nonspecific antimicrobial factors (Hagiwara et al., 2000). In the newborn, these molecules act synergistically with maternal Ig ingested (Playford et al., 2000) and are involved in the regulation of intestinal repair after inflammation (Elson and Beagly, 1994).

No conclusion could be drawn up from survival data, owing to the lack of significant difference between the 2 groups. A previous trial conducted by Mellado et al. (2008) showed that supplementation in colostrum can reduce the mortality rate of youngs. Abdou et al. (2013) studied the survival rate of kids from both groups on a larger period. The mortality rate was highly reduced (5 vs $20 \%$ for the ColG and ConG respectively).

\section{Conclusion and prospect}

Our observations suggest that the distribution, early in life, of colostrum from Azawak cow to Red kids is likely to improve their resistance to environmental constraints. This was indicated by higher plasma levels for several protein fractions such as total globulins and total proteins. The supplementation contributed to maintain the plasma protein homeostasis and the effect was preserved at least two weeks after the end of the supplementation. This phenomenon probably helped to improve the healthiness of kids.

\section{Acknowledgements}

This work was subsidized by Belgian Technical Cooperation (BTC). The authors wish to thank the organization.

\section{References}

Abdou, H., Marichatou, H., Beckers, J.-F., Dufrasne, I., Issa, M., Hornick, J.L., 2013. Effect of bovine colostrum intake on animal performance, reproductive parameters and survival in Red kids. J. Anim. Physiol. Anim. Nutr., http://dx.doi.org/10.1111/jpn.12143.

Ajello, M., Greco, R., Giansanti, F., Massucci, M.T., Antonini, G., Valenti, P., 2002. Anti- invasive activity of bovine lactoferrin towards group A streptococci. Biochem. Cell Biol. 80, 119-124.
AOAC, 2006. Association of Official Analytical Chemists, Current through revision 1, 18th ed. AOAC International, Arlington, VA, USA.

Argüello, A., Castro, N., Zamorano, M.J., Castroalonso, A., Capote, J., 2004. Passive transfer of immunity in kid goats fed refrigerated and frozen goat colostrum and commercial sheep colostrum. Small Rumin. Res. $54,237-241$

Alloncle, F., (Thèse de doctorat vétérinaire) 1980. Essais de prévention et de traitement des maladies néonatales du veau à l'aide d'un sérocolostrum hyperimmun d'origine bovine. Ecole Nationale Vétérinaire d'Alfort, Alfort.

Ben Romdhane, S., Romdhane, M.N., Ben Yahia, H., Sanhaji, H., Feki, M., M'Bazaa, A., 2001. Estimation du transfert de l'immunité colostrale par la recherche de l'activité de la GGT et des protéines sériques chez le chamelon nouveau-né (Camelus dromedarius). Rev. Méd. Vét. 152, 843-850.

Boudry, C., Dehoux, J-P., Wavreille, J., Portetelle, D., Théwis, A., Buldgen, A., 2008. Effect of a bovine colostrum whey supplementation on growth performance, faecal Escherichia coli population and systemic immune response of piglets at weaning. Animal 2, 730-737.

Castro, N., Capote, J., Alvarez, S.A., Argüello, A., 2005. Effects of lyophilized colostrum and different colostrum feeding regimens on passive transfer of immunoglobulin G in Majorera goat kids. J. Dairy Sci. 88, 3650-3654.

Chaibou, M., (Thèse de Doctorat ès sciences) 2005. Productivité zootechnique du désert: le cas du bassin laitier d'Agadez au Niger. Université de Montpellier II, Montpellier.

Di Mario, F., Aragona, G., Bò, N.D., Ingegnoli, A., Cavestro, G.M., Moussa, A.M., Iori, V., Leandro, G., Pilotto, A., Franzè, A., 2003. Use of lactoferrin for Helicobacter pylori eradication. Preliminary results. J. Clin. Gastroenterol. 36, 396-398

Edwards, S.A., 2002. Perinatal mortality in the pig: environmental or physiological solutions? Livest. Prod. Sci. 78, 3-12.

Elson, C.O., Beagly, K.W., 1994. Cytokines et de médiateurs immunitaires. In: Johnson, L.R. (Ed.), Physiology of the Gastro-Intestinal Tract. Raven, New York, pp. 243-266.

Godden, S.M., Haines, D.M., Konkol, K., Peterson, J., 2009. Improving passive transfer of immunoglobulins in calves. II. Interaction between feeding method and volume of colostrum fed. J. Dairy Sci. 92, 1758-1764.

Hadorn, U., Blum, J.W., 1997. Effects of feeding colostrums, glucose or water on the first day of life on plasma immunoglobulin $G$ concentrations and GGT activities in calves. J. Vet. Med. A 44, 531-537.

Hagiwara, K., Kataoka, S., Yamanaka, H., Kirisawa, R., Iwai, H., 2000. Detection of cytokines in bovine colostrum. Vet. Immunol. Immunopathol. 76, 183-190.

Hamadeh, S.K., Hatfield, P.G., Kott, R.W., Sowell, B.F., Robinson, B.L., Roth, N.J., 2013. Effects of breed, sex, birth type and colostrum intake on cold tolerance in newborn lambs. Sheep Goat Res. J. 16 (2), 46-51.

Huguet, A., Le Normand, L., Fauquant, J., Kaeffer, B., Le Huërou-Luron, I., 2007. Influence of bovine colostrum on restoration of intestinal mucosa in weaned piglets. Livest. Sci. 108, 20-22.

Kaneko, J.J., Harvey, J., Bruss, M., 1997. Clinical Biochemistry of Domestic Animals, 5th ed. Academic Press, San Diego.

King, M.R., Morel, P.H.C., Revell, D.K., Pluske, J.R., Birtles, M.J., 2008. Dietary bovine colostrum increases villus height and decreases small intestine weight in early-weaned pigs. Asian-Aust. J. Anim. Sci. 21, 567-573.

Le Dividich, J., Martineau, G.B., Thomas, F., Demay, H., Renoux, H., Homo, C., Boutin, D., Gaillard, L., Surel, Y., Bouetard, M., Massard, M., 2004. Production colostrale, immunité et survie des porcelets. Journées Rech. Porcine 36, 451-456.

Le Huërou-Luron, I., Hughet, A., Callarec, J., Leroux, T., Le Dividich, J., 2004. Supplementation of a weaning diet with bovine colostrum increases feed intake and growth of weaned piglets. Journées Rech. Porcine 36, 33-38.

Lima, A.L., Moretti, D.B., Nordi, W.M., Pauletti, P., Susin, I., Machado-Neto, I., 2013. Electrophoretic profile of serum pro-teins of goat kids fed with bovine colostrum in natura and lyophilized. Small Rumin. Res. http://dx.doi.org/10.1016/j.smallrumres.2013.02.013.

Lima, A.L., Pauletti, P., Susin, I., Machado Neto, R., 2009. Fluctuation of serum variables in goats and comparative study of antibody absorption in new-born kids using cattle and goat colostrum. Rev. Bras. Zootec 38, 2211-2217.

Marion, J., Le Huerou-Luron, I., Huguet, A., Callrec, J., Leroux, T., Le Dividich, J., 2002. La supplémentation de l'aliment de sevrage en un extrait de colostrum bovin augmente la hauteur des villosités dans le duodénum chez le porcelet sevré. Journées Rech. Porcine 34, 103-108.

Mayer, B., Zolnai, A., Frenyo, L.V., Jancsik, V., Szentirmay, Z.N., Hammarstro, L., Kacskovics, I., 2002. Redistribution of the sheep neonatal Fc receptor in the mammary gland around the time of parturition in ewes and its 
localization in the small intestine of neonatal lambs. Immunology 107 288-296.

Mellado, M., Pittroff, W., García, J.E., Mellado, J., 2008. Serum IgG, blood profiles, growth and survival in goat kids supplemented with artificial colostrum on the first day of life. Trop. Anim. Health Prod. 40, 141145

Morales-delaNuez, A., Moreno-Indias, I., Sánchez-Macías, D., Capote, J., Juste, M.C., Castro, N., Hernández-Castellano, L.E., Argüello, A., 2011. Sodium dodecyl sulfate reduces bacterial contamination in goat colostrum without negative effects on immune passive transfer in goat kids. J. Dairy Sci. 94, 410-415

Moretti, D.B., Kindlein, L., Pauletti, P., Machado-Neto, R., 2010. IgG absorption by santa Ines lambs fed Holstein bovine colostrum or Santa Ines ovine colostrum. Animal 6, 933-937.

Moretti, D.B., Nordi, W.M., Lima, A.L., Pauletti, P., Susin, I., Machado-Neto, R., 2012. Lyophilized bovine colostrum as a source of immunoglobulin and insulin-like growth factor for newborn goat kids. Livest. Sci. 144, $1-10$.

Naba, A.M., (Thèse de doctorat vétérinaire) 2001. Contribution à l'évaluation technique du projet d'appui à la sélection, la promotion et la diffusion de la chèvre rousse de Maradi-Niger. Ecole Inter-États des Sciences et Médecine Vétérinaire de Dakar, Dakar.

N'Diaye-Wereme, A., Grongnet,J.F., Tamboura, H., Nianogo, A.J., Sawadogo, L., 1998. L'acquisition de l'immunité passive par le chevreau nouveauné de race Naine Mossi. Rôle d'une assistance à la tétée. Rev. Élev Méd. Vét. Pays Trop. 51, 289-292.

Nowak, R., Poindron, P., 2006. From birth to colostrum: early steps leading to lamb survival. Reprod. Nutr. Dev. 46, 431-446.
Payne, J.M., Payne, S., 1987. The Metabolic Profil Test. Oxford University Press, New York.

Playford, R.J., Macdonald, C.E., Johnson, W.S., 2000. Colostrum and milkderived peptide growth factors for the treatment of gastro-intestinal disorders. Am. J. Clin. Nutr. 72, 5-14.

Rawal, P., Gupta, V., Thapa, B.R., 2008. Role of colostrum in gastrointestinal infection. Indian J. Pediatr. 75, 917.

Rodríguez, C., Castro, N., Capote, J., Morales-delaNuez, A., MorenoIndias, I., Sánchez-Macías, D., Argüello, A., 2009. Effect of colostrum immunoglobulin concentration on immunity in Majorera goat kids. J. Dairy Sci. 92, 1696-1701.

Silim, A., Rekik, M.R., Roy, R.S., Salmon, H., Pastoret, P.P., 1990. Immunité chez le fotus et le nouveau-né. In: Pastoret, P.P., Govaerts, A. (Eds.), Immunologie Animale. Paris, Flammarion, pp. 197-204.

SAS, 1999. Statistical Analysis System SAS/STAT. User's Guide, 5th ed., 8.2 versions (Cary, NC, USA).

Stelwagen, K., Carpenter, E., Haigh, B., Hodgkinson, A., Wheeler, T.T., 2009. Immune components of bovine colostrum and milk. J. Anim. Sci. 87, 3-9.

Tuscherer, M., Puppe, B., Tuscherer, A., Tieman, U., 2000. Early identification of neonates at risk: traits of newborn piglets with respect to survival. Theriogenology 54, 371-388.

Oumara, A.D., (Thèse de doctorat vétérinaire) 1986. Croissance et viabilité de la chèvre rousse de Maradi au centre d'élevage caprin de Maradi. École Inter-Étas de sciences et médecine vétérinaire de Dakar, Dakar.

Yamauchi, K., Wakabayashi, H., Hashimoto, S., Teraguchi, S., Hayasawa, H., Tomita, M., 1998. Effects of orally administered bovine lactoferrin on the immune system of healthy volunteers. Adv. Exp. Med. Biol. 443, 261-265. 